\title{
Effect of Brine Disposal on Seawater Quality at Az-Zour Desalination Plant in Kuwait: Physical and Chemical Properties
}

\author{
Saud Bali Al-Shammari ${ }^{1}$ and Lulwa $\mathrm{Ali}^{2}$ \\ 1. Environmental Health Department, College of Health Sciences, The Public Authority for Applied Education and Training, Faiha \\ 72853, Kuwait \\ 2. Environmental Science Department, Kuwait Institute for Scientific Research, Safat 13109, Kuwait
}

\begin{abstract}
Seawater desalination has become the only viable source of fresh water for Kuwait. However, desalination plants could have several impacts on the surrounding marine environment. The major concern of these impacts surrounds the outfall effluent discharge because of its physical and chemical features including high temperature and salinity associated with residual chemicals used in the pretreatment process. In this study assessment of potential impact of Az-Zour desalination plant discharge effluent on marine environment was carried out. The assessment consisted of field measurements and numerical modelling of effluent dispersion. The results revealed a potential impact by temperature and salinity between 4 and $6{ }^{\circ} \mathrm{C}$ and 2-4 ppt above ambient and mean levels for Kuwait seawater. The predictions of hydrodynamic modelling show that the plume from the outfall runs parallel to the shoreline and the influenced area can reach to about $40 \mathrm{~km}^{2}$.
\end{abstract}

Key words: Desalination, impact, seawater, assessment.

\section{Introduction}

Most of the arid and semi-arid countries suffer from the scarcity of water resources and this is considered as the major challenge that has to be faced. Severe water shortages can lead to the deterioration of a person's health and may severely constrain the development of the community. These countries have turned to desalination of seawater as a solution to this growing problem [1]. Desalination is the process by which freshwater is extracted from saline waters, such as seawater and brackish water. Commercially available desalination techniques are categorized either as distillation-based or as membrane-based technologies. Distillation-based processes are MSF (Multi Stage Flash), MED (Multiple Effect Distillation), and VC (Vapor Compression). Main

Corresponding author: Saud Bali Al-Shammari, Ph.D., associate professor, research fields: water and wastewater treatment, environmental engineering and seawater desalination. E-mail: sb.alshemmari@paaet.edu.kw, s.b.alwan@gmail.com. membrane-based processes are Reverse Osmosis (RO). Distillation-based processes involve phase changes. In Kuwait, water resources are very limited and most of the fresh water is produced by desalting Gulf seawater. During the last five decades, Kuwait has developed six MSF dual-purpose plants for water production and power generation, along a $120-\mathrm{km}$ shoreline [2]. Seawater desalination by MSF process generally requires a large seawater inlet flow resulting in an increase in salinity of the discharge flow known as brine. Various chemicals are added to the feed water to control formation of mineral scale and biological growth that would otherwise interfere with the processes [3]. These chemicals or their reaction products are in-turn discharged with the reject brine. Cooling water used in the steam turbine generators is also discharged to the sea with higher temperature than the ambient temperature of the surface seawater. The potential negative impacts associated with desalination plant operation have gained an 
international attention [4]. The introduction of concentrated brine waste effluent has been historically considered a major environmental concern with desalination plants particularly on marine ecosystem [5-8]. The discharged brine is characterized by increased salinity and elevated temperature. It additionally contains substantial amounts of chemical pollutants, such as chlorine (which is used for biofouling control in the plants), antiscalants (which are used for scale inhibition) and heavy metals (which are present due to corrosion). Desalination impacts on marine environment vary widely and are typically based on the specifics of each site. The degree of the impacts in a large part depends on overall plant design and operation, methods used for effluent disposal and specific physical and biological conditions near the plant. This aim of this work is to study the physical and chemical impacts caused by the effluent discharge from Az-Zour desalination plant in Kuwait on the local marine environment.

\section{Desalination in Kuwait}

In Kuwait, six coastal sites were developed to produce distilled water and electrical energy as shown in Fig. 1. Total current installed nominal capacity amounts to 2.81 million $\mathrm{m}^{3} / \mathrm{d}$ [2]. The MEW (Ministry of Energy \& Water) operates the MSF distillation plants at high temperature, mainly during high demand season (summer), whereas, operation at normal temperature is adopted during the rest of the year. Details of the installed capacity of the existing distillation plants in Kuwait are listed in Table 1.

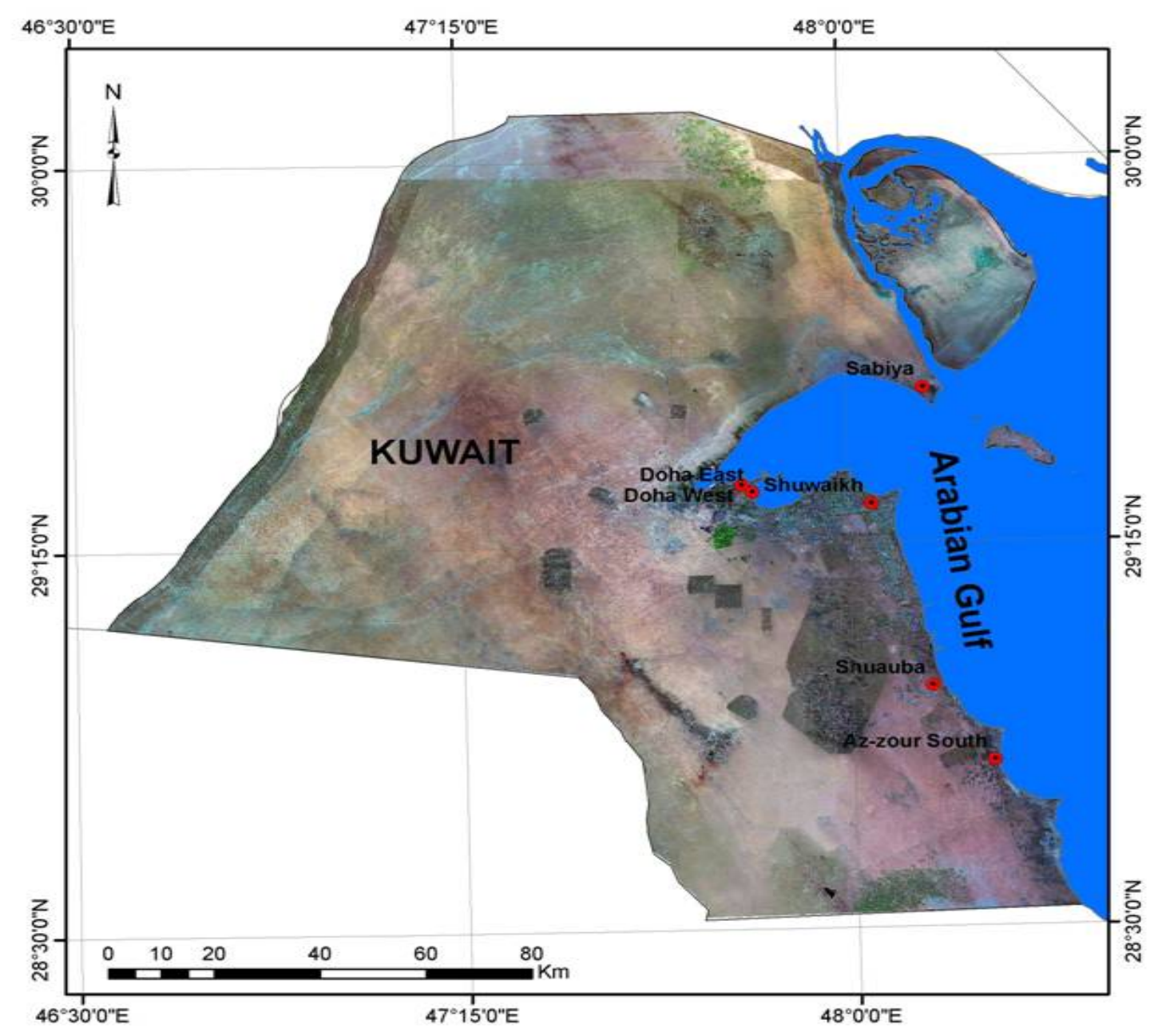

Fig. 1 Desalination and power plants in Kuwait. 
Table 1 Installed capacity of the distillation plants in Kuwait.

\begin{tabular}{ll}
\hline Plant & Total capacity $\left(\right.$ million $\left.\mathrm{m}^{3} / \mathrm{d}\right)$ \\
\hline Shuwaikh & 0.221 \\
Shuaiba & 0.161 \\
Doha East & 0.189 \\
Doha West & 0.500 \\
Az-Zour South & 0.649 \\
Sabiya & 0.448 \\
Total & 2.81 \\
\hline
\end{tabular}

\section{Marine Environment Concerns}

The Arabian Gulf represents an extreme case as to the undesirable environmental effects associated with brine disposal in comparison to other seas. This is because of the huge amount of desalination activities located relatively within close distance along the western seashores of the Gulf, which are considered the biggest of their kind in the world, and due to the distinctive characteristics of the Gulf itself in terms of the restrictions to the natural seawater circulation and evaporation rates. Hence, examining the case of its Arabian Gulf is useful in magnifying the impact of desalination on the marine environment, and hence, drawing a conservative conclusion on the extent of the undesirable effects. The natural circulation exchanges water between the Arabian Gulf and the Gulf of Oman via the Strait of Hormuz. The circulation in and out of the Strait of Hormuz is believed to be very limited with a residence time estimated to be in the range of 2 to 5 years $[9,10]$. The evaporation is very high for most of the year, estimated at a rate between 140 and $500 \mathrm{~cm} /$ year [11]. Evaporation from the surface of the Gulf seawater exceeds the total river runoff and rainfalls by approximately a factor of 10 [12]. All these factors together contribute to making the salinity higher in comparison to other open seas. Salinity of the Gulf seawater varies seasonally, on the average, from 38,000 to $45,000 \mathrm{mg} / \mathrm{L}$. In general, the salinity is higher during summer and fall, as compared to winter and spring seasons. Temperature of the Gulf seawater ranges from 12 to $35{ }^{\circ} \mathrm{C}$ in the winter and summer, respectively, with an average of $23.1^{\circ} \mathrm{C}$ [13]. Thermal desalination plants discharge the concentrate usually with a temperature of 5 to $10{ }^{\circ} \mathrm{C}$ above ambient seawater temperature [5]. However, several authors investigated the effect of hot brine and they found that a small temperature elevation was noticed when discharging effluent at a temperature of $10-15{ }^{\circ} \mathrm{C}$ above ambient seawater temperature [14].

\section{Material and Methods}

\subsection{Study Area and Sampling Locations}

A total area of about $2 \mathrm{~km}$ at the vicinity of the marine area of Az-Zour desalination and power plant was assessed as shown in Fig. 2. Transects were established perpendicular to the coast and extend $2 \mathrm{~km}$ north and south or east and west from the outfall channel, taking into consideration the local condition and the technical specification of the intake and outfall channel. About 15 to 20 sampling points from 3 to 5 transects were selected, and sampling stations at successive increasing intervals from the outfall point were identified by GPS (Global Positioning System). Two water depths including surface and bottom were included in the assessment at these sites when feasible.

\subsection{Sampling Procedure}

Two sampling programs were carried out in the study. The first field sampling program was carried out between 6 and 28 August 2007. This program represented the summer season. The second sampling was carried out between 18 February and 25 March 2008 and represented the spring season. The sampling programs were hampered by the prevailing weather conditions, and thus, were done when conditions allowed. The surveyed stations with their GPS locations and water depth are shown and given in Table 2 and Fig. 3. Sampling was conducted according to the ROPME (Regional Organization for the Protection of Marine Environment) Manual [15]. In addition, water samples were also collected from more than one position within the plant. The sampling positions included the 


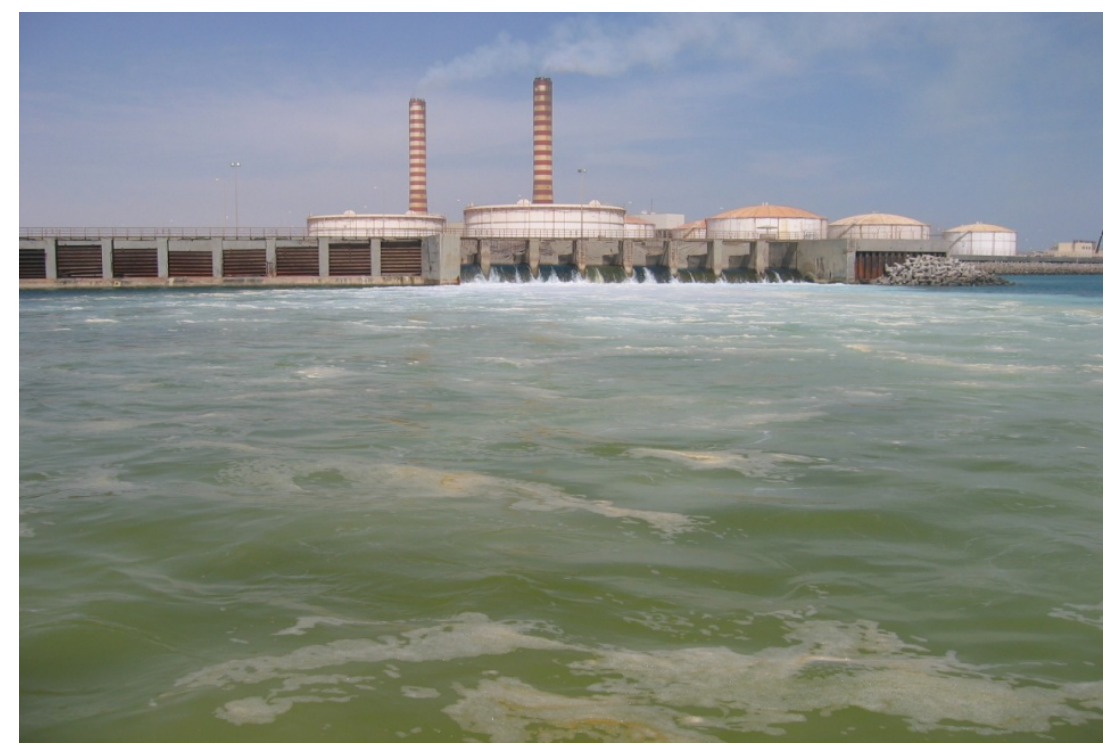

Fig. 2 Az-Zour desalination plant and outfall structure.

Table 2 Location and water depth of sampling stations at the study area of Az-Zour desalination plant.

\begin{tabular}{|c|c|c|c|c|}
\hline \multirow{2}{*}{$\begin{array}{l}\text { Station } \\
\text { code }\end{array}$} & \multirow{2}{*}{$\begin{array}{l}\begin{array}{l}\text { Distance } \\
(\mathrm{m})^{* *} \\
/ \text { Transict }\end{array} \\
100 \mathrm{E}\end{array}$} & \multicolumn{2}{|c|}{$\begin{array}{l}\text { GPS Coordinate } \\
\text { North East }\end{array}$} & \multirow{2}{*}{$\begin{array}{l}\begin{array}{l}\text { Water } \\
\text { depth } \\
(\mathrm{m})^{*}\end{array} \\
1.7\end{array}$} \\
\hline & & 28.69843 & 48.37995 & \\
\hline Zr 2 & $300 \mathrm{SE}$ & 28.69688 & 48.38183 & 5.2 \\
\hline Zr 3 & $100 \mathrm{~S}$ & 28.69774 & 48.37962 & 2.5 \\
\hline Zr 4 & $100 \mathrm{~N}$ & 28.69981 & 48.38006 & 4.8 \\
\hline $\mathrm{Zr} 7$ & $300 \mathrm{NE}$ & 28.7 & 48.38006 & 5.4 \\
\hline $\operatorname{Zr} 8$ & $500 \mathrm{SSE}$ & 28.69366 & 48.38226 & 4.6 \\
\hline Zr 9 & $500 \mathrm{ESE}$ & 28.69398 & 48.38793 & 5.5 \\
\hline Zr 10 & $800 \mathrm{NE}$ & 28.70015 & 48.3866 & 5.4 \\
\hline Zr 11 & $500 \mathrm{NE}$ & 28.70155 & 48.38408 & 5.3 \\
\hline $\operatorname{Zr} 12$ & 1000 ESE & 28.69398 & 48.38793 & 5.8 \\
\hline Zr 13 & $1000 \mathrm{E}$ & 28.6979 & 48.3899 & 6.1 \\
\hline Zr 14 & $1000 \mathrm{SE}$ & 28.691 & 48.3878 & 5.6 \\
\hline Zr 15 & $1000 \mathrm{NE}$ & 28.70298 & 48.38868 & 8.9 \\
\hline Zr 16 & $2000 \mathrm{SE}$ & 28.6892 & 48.39591 & 5.0 \\
\hline Zr 17 & $2000 \mathrm{E}$ & 28.6971 & 48.39883 & 6.6 \\
\hline Zr 18 & $2000 \mathrm{SSE}$ & 28.68405 & 48.39 & 4.0 \\
\hline Zr 19 & $2000 \mathrm{ESE}$ & 28.69037 & 48.39693 & 6.7 \\
\hline $\mathrm{Zr} 20$ & $600 \mathrm{~N}$ & 28.70376 & 48.38723 & 3.3 \\
\hline $\begin{array}{l}\text { Zr 21- } \\
\text { Control }\end{array}$ & $2000 \mathrm{NE}$ & 28.70758 & 48.39723 & 7.0 \\
\hline
\end{tabular}

* Depth as measured at the time of sampling.

** Distance and direction from the outfall point; N (North); NE (Northeast); E (East); S (South); SE (Southeast); SSE (South-southeast); ESE (East-southeast).

brine effluents discharged from the desalination units them self (i.e. reject brine in the syphon shaft), the effluent discharged from the power plant only (cooling water discharge) and effluent discharge at the outfall point of the plants (i.e., the mixing zone of the effluent from the distillation and power units together).

\subsection{Analytical Measurements}

All samples were analyzed to measure the physico-chemical characteristics of water including water temperature, salinity, $\mathrm{pH}$, Dissolved Oxygen (DO) and conductivity at each sampling station and selected depth. The laboratory chemical analyses of collected samples included measurement of both inorganic and organic parameters. The work of all chemical analysis to determine the elements chemical readings was made according to the standard methods [16].

\subsection{Numerical Modeling Assessment}

The RMA-10 hydrodynamic model was used in this study to investigate the plume dispersion and simulate different scenarios of plume impacts. RMA (Resource Modeling Associates) developed the model, which is capable of modeling tidal fluctuation, current, temperature, salinity and conservative material. The model is based on the finite element technique and has the advantage of using a non-structured grid for the domain network. 


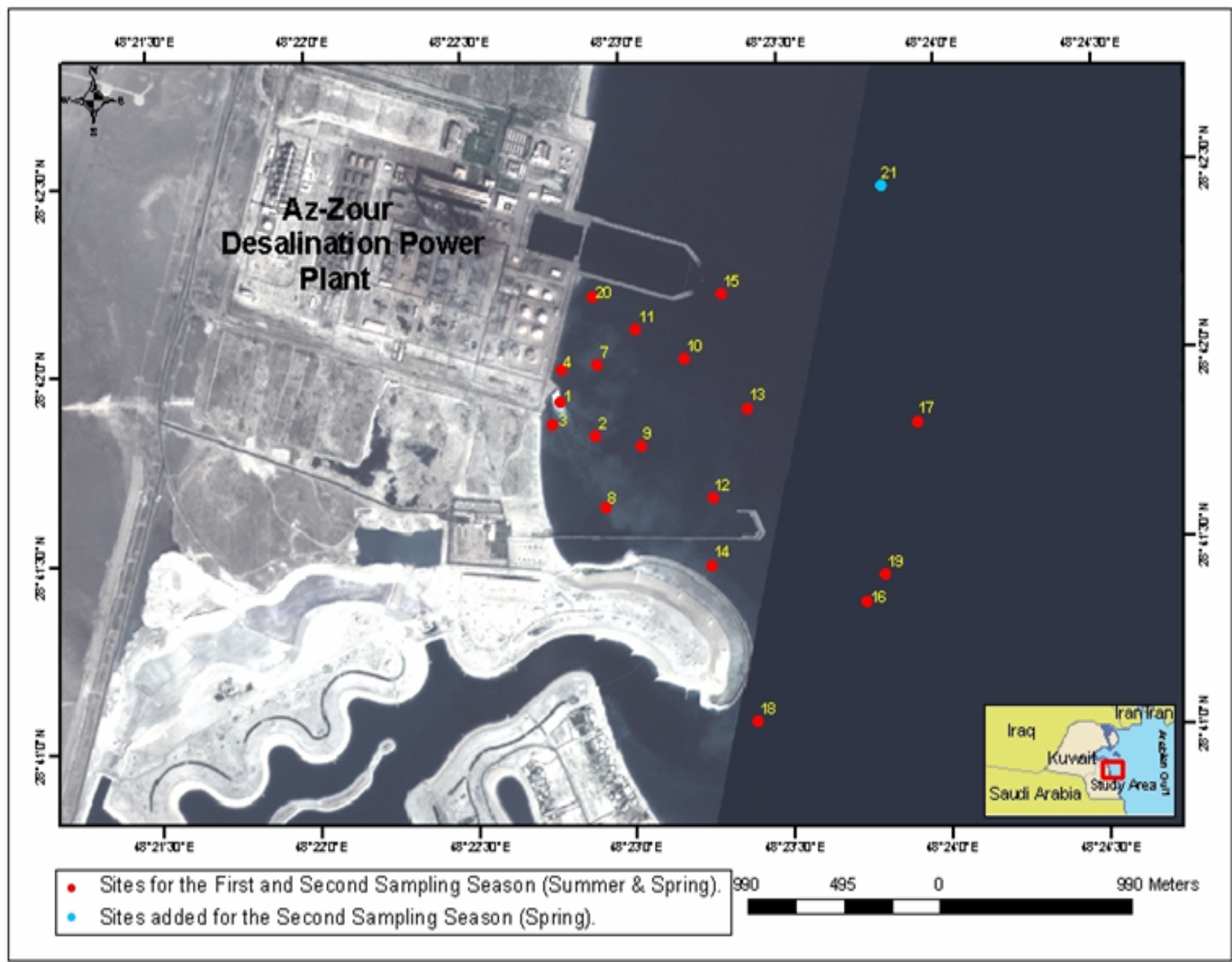

Fig. 3 The sampling stations at the study area of Az-Zour desalination plant.

\section{Results and Discussion}

\subsection{Impact of Temperature Rise}

Water quality measurement at the vicinity of Az-Zour plant was carried out twice in two seasons; summer season in August 2007 and in spring in March 2008. In summer, water temperature was found to range between $33{ }^{\circ} \mathrm{C}$ (at $\mathrm{Zr} 19$ located 2,000 m ESE direction from the outlet), and $37.55{ }^{\circ} \mathrm{C}$ (at $\mathrm{Zr} 3$ located at the discharge point at $100 \mathrm{~m}$ south) in the surface water layer. In the bottom water, the temperature ranged between a minimum of $33{ }^{\circ} \mathrm{C}$ (at Zr 19 located 2,000 m ESE and Zr 20 located $200 \mathrm{~m}$ north the outlet), and $38.7{ }^{\circ} \mathrm{C}$ at station $\mathrm{Zr} 7(300 \mathrm{~m}$ $\mathrm{NE}$ of the outlet) with an average of $35.01 \pm 0.38{ }^{\circ} \mathrm{C}$, for both surface and bottom water temperature (Table
3). In general, temperatures distribution showed a decreasing trend from the outfall discharge point toward offshore. On the average, 2 to $3{ }^{\circ} \mathrm{C}$ difference in temperature was noted between stations close to the discharge point, and those further away $(>1.5 \mathrm{~km})$ (Fig. 4). Spatial distribution of temperature in the surface layer and the same in the bottom water layer during this season are shown in Figs. 4 and 5.

During spring, the temperature in the surface water layer ranged between a minimum of $16.25{ }^{\circ} \mathrm{C}$ at station $\mathrm{Zr} 19$ (2,000 $\mathrm{m}$ southeast direction from the outfall) and a maximum of $24{ }^{\circ} \mathrm{C}$ at station $\mathrm{Zr} 14$ (located about 1,000 $\mathrm{m}$ southeast the outlet along the directions of the discharge) (Table 3 ). The plume results in an increase of $6{ }^{\circ} \mathrm{C}$ above ambient water temperature during this time of the year. Stratification 
within the water column was generally stubble. However, differences in water temperature attributed to stratification were demonstrated at stations $\mathrm{Zr}$ 1, Zr 8, $\mathrm{Zr} 15$ and $\mathrm{Zr} 20$ where surface temperature was more than temperature of bottom water layers by 2.85 , 2.69, 1.1 and $1.83{ }^{\circ} \mathrm{C}$, respectively (Table 3 and Fig. 5). The increase signified in surface temperature at $\mathrm{Zr}$ 15 and $\mathrm{Zr} 20$ is of particular importance as these stations located at the area of the plant water intake, and thus may be contributing to increase in water temperature at the plant intake. This increase, unlike in summer season where the ambient temperature is already high, is an advantage in the winter for the desalination process. In contrast, stations $\mathrm{Zr} 8, \mathrm{Zr} 9$ and $\mathrm{Zr} 14$ exhibited higher temperatures at the bottom water layers compared to the surface temperature $\left(+1.6,+4.49\right.$ and $+2{ }^{\circ} \mathrm{C}$, respectively) at the vicinity of $\mathrm{Zr}$ desalination plant (Figs. 4 and 5). Thermal increase ranged between 4 and $6{ }^{\circ} \mathrm{C}$. These temperatures are low when compared to Kuwait guidelines for industrial wastewater discharge to the sea. According to these guidelines, the maximum allowable limit for discharge of industrial wastewater to the sea is $\leq$ $10{ }^{\circ} \mathrm{C}$, calculated as the difference between the temperature of discharged water and that of the intake [17].

Table 3 Water quality measured at the vicinity of Az-Zour desalination plant.

\begin{tabular}{|c|c|c|c|c|c|c|c|c|c|c|c|}
\hline \multirow{2}{*}{$\begin{array}{l}\text { Station } \\
\text { code }\end{array}$} & \multirow[t]{2}{*}{ Level } & \multicolumn{2}{|c|}{$\begin{array}{l}\text { Conductivity (EC) } \\
(\mathrm{ms} / \mathrm{m})\end{array}$} & \multicolumn{2}{|c|}{ DO (mg/L) } & \multicolumn{2}{|c|}{$\mathrm{pH}$} & \multicolumn{2}{|c|}{$\begin{array}{l}\text { Water temp. } \\
\left({ }^{\circ} \mathrm{C}\right)\end{array}$} & \multicolumn{2}{|l|}{$\begin{array}{l}\text { Salinity } \\
\text { (ppt) }\end{array}$} \\
\hline & & Summer & Spring & Summer & Spring & Summer & Spring & Summer & Spring & Summer & Spring \\
\hline \multirow{2}{*}{ Zr-1 } & Top. & 63.74 & - & - & 6.65 & 7.68 & 7.93 & 37.41 & 23.1 & 42.56 & 40.02 \\
\hline & Bott. & - & - & - & 6.97 & - & 7.91 & - & 20.25 & - & 39.76 \\
\hline \multirow{2}{*}{$\mathrm{Zr}-2$} & Top. & 61.63 & - & - & 6.57 & 8.88 & 7.94 & 35.27 & 21.57 & 41.06 & 39.2 \\
\hline & Bott. & 64.4 & - & - & 6.83 & 8.87 & 7.94 & 35.32 & 21.43 & 43.15 & 39.65 \\
\hline \multirow{2}{*}{$\mathrm{Zr3}$} & Top. & 65.14 & - & - & 6.7 & 8.63 & 7.93 & 37.55 & 22.73 & 43.66 & 40.56 \\
\hline & Bott. & - & - & - & 6.75 & - & 7.92 & - & 22.5 & - & 37.56 \\
\hline \multirow{2}{*}{$\mathrm{Zr} 4$} & Top. & 63.98 & - & - & 6.61 & 8.65 & 7.92 & 34.1 & 21.53 & 42.91 & 39.51 \\
\hline & Bott. & 65.3 & - & - & 6.66 & 8.88 & 7.93 & 37.38 & 21.03 & 43.75 & 39.1 \\
\hline \multirow{2}{*}{$\mathrm{Zr}-7$} & Top. & 63.54 & - & - & 6.57 & 8.88 & 7.93 & 33.74 & 21.02 & 42.59 & 40.67 \\
\hline & Bott. & 63.55 & - & - & 6.69 & 8.87 & 7.91 & 38.72 & 20.22 & 42.59 & 38.6 \\
\hline \multirow{2}{*}{ Zr-8 } & Top. & 65.3 & - & - & 7.14 & 8.88 & 7.92 & 37.38 & 21.84 & 43.75 & 38.18 \\
\hline & Bott. & 65.27 & - & - & 6.89 & 8.85 & 7.92 & 37.38 & 22.18 & 43.74 & 39.54 \\
\hline \multirow{2}{*}{ Zr-9 } & Top. & 63.37 & - & - & 7.24 & 8.86 & 7.91 & 33.76 & 19.49 & 42.48 & 38.46 \\
\hline & Bott. & 63.88 & - & - & 7.12 & 8.86 & 7.92 & 34.18 & 24.3 & 42.88 & 35.2 \\
\hline \multirow{2}{*}{ Zr-10 } & Top. & 64.22 & - & - & 7.19 & 8.85 & 7.91 & 35.16 & 19.81 & 43.14 & 40.39 \\
\hline & Bott. & 63.39 & - & - & 7.24 & 8.84 & 7.91 & 34.6 & 19.49 & 42.83 & 38.46 \\
\hline \multirow{2}{*}{ Zr-11 } & Top. & 64.44 & - & - & 7.33 & 8.85 & 7.93 & 35.56 & 19.59 & 43.18 & 41.77 \\
\hline & Bott. & 63.59 & - & - & 7.19 & 8.81 & 7.91 & 34.76 & 19.53 & 42.6 & 40.71 \\
\hline \multirow{2}{*}{$\mathrm{Zr}-12$} & Top. & 63.36 & - & - & 7.41 & 8.86 & 7.37 & 33.83 & 17.71 & 42.45 & 40.69 \\
\hline & Bott. & 63.72 & - & - & 7.33 & 8.85 & 7.9 & 34.06 & 18.52 & 42.72 & 40 \\
\hline \multirow{2}{*}{$\mathrm{Zr}-13$} & Top. & 64.43 & - & - & 7.46 & 8.85 & 7.83 & 35.72 & 16.83 & 43.17 & 40.73 \\
\hline & Bott. & 63.85 & - & - & 7.15 & 8.84 & 7.86 & 34.53 & 17.21 & 42.81 & 39.42 \\
\hline \multirow{2}{*}{$\mathrm{Zr}-14$} & Top. & 63.99 & - & - & 7.08 & 8.86 & 6.98 & 34.52 & 24 & 42.9 & 42.09 \\
\hline & Bott. & 63.99 & - & - & 7.06 & 8.86 & 7.93 & 34.52 & 260 & 42.9 & 40.65 \\
\hline \multirow{2}{*}{ Zr-15 } & Top. & 35.32 & - & - & 7.4 & 8.86 & 7.85 & 34.98 & 16.96 & 42.9 & 39.89 \\
\hline & Bott. & 63.6 & - & - & 7.55 & 8.84 & 7.84 & 34.22 & 15.86 & 42.6 & 38.69 \\
\hline \multirow{2}{*}{ Zr-16 } & Top. & 77.91 & - & - & 7.39 & 8.65 & 7.81 & 35.91 & 18.2 & 43.24 & 40.54 \\
\hline & Bott. & 76.55 & - & - & 7.54 & 8.81 & 7.8 & 34.6 & 18.5 & 43.43 & 39.49 \\
\hline
\end{tabular}


Table 3 to be continued

\begin{tabular}{llllllllllll}
\hline \multirow{2}{*}{ Zr-17 } & Top. & 72.66 & - & - & 7.55 & 8.8 & 7.86 & 33.33 & 16.92 & 41.96 & 40.66 \\
& Midd. & 72.61 & - & - & & 8.78 & - & 33.29 & - & 40.95 & - \\
& Bott. & 72.61 & - & - & 7.28 & 8.72 & 7.84 & 33.28 & 16.68 & 41.97 & 39.3 \\
Zr-18 & Top. & 77.4 & - & - & 6.93 & 8.66 & 7.88 & 35.4 & 17.19 & 43.28 & 41.36 \\
& Bott. & 76.5 & - & - & 7.07 & 8.77 & 9.08 & 34.8 & 18.39 & 43.23 & 40.01 \\
& Top. & 71.98 & - & - & 7.35 & 8.76 & 7.85 & 33 & 16.25 & 41.78 & 40.09 \\
Zr-19 & Midd. & - & - & - & - & - & - & - & - & - & - \\
& Bott. & 72.05 & - & - & 7.04 & 8.62 & 7.85 & 33.01 & 16.5 & 41.82 & 39.14 \\
Zr-20 & Top. & 64.38 & - & - & 7.1 & 8.36 & 7.93 & 35.03 & 21.56 & 43.18 & 40.56 \\
& Bott. & 63.59 & - & - & 6.99 & 8.81 & 7.89 & 34.76 & 19.73 & 42.6 & 39.00 \\
Zr-21 & Top. & - & - & - & 7.24 & - & 7.88 & - & 20.06 & - & 40.17 \\
& Bott. & - & - & - & & - & 7.84 & - & 18.8 & - & 38.51 \\
Max. & Top. & 77.91 & - & 4.97 & 7.55 & 8.88 & 7.94 & 37.55 & 24 & 43.75 & 42.09 \\
& Midd. & 72.61 & - & 2.28 & & 8.78 & - & 33.29 & - & 40.95 & - \\
& Bott. & 76.55 & - & 4.50 & 7.55 & 8.88 & 9.08 & 38.72 & 26 & 43.75 & 40.71 \\
\multirow{2}{*}{ Min. } & Top. & 35.32 & - & 1.28 & 6.57 & 7.68 & 6.98 & 33.00 & 16.25 & 41.06 & 38.18 \\
& Midd. & 72.61 & - & 2.28 & & 8.78 & - & 33.29 & - & 40.95 & - \\
& Bott. & 63.39 & - & 2.15 & 6.66 & 8.62 & 7.80 & 33.01 & 15.86 & 41.82 & 12.07 \\
STDEV & Top. & 8.85 & - & 0.85 & 0.33 & 0.29 & 0.24 & 1.37 & 2.40 & 0.67 & 0.98 \\
& Bott. & 4.82 & - & 0.51 & 0.26 & 0.07 & 0.28 & 1.53 & 2.64 & 0.53 & 6.32 \\
Average & Top. & 64.82 & - & 2.85 & 7.1 & 8.71 & 7.82 & 35.09 & 19.81 & 42.79 & 40.29 \\
\hline & Bott. & 66.620 & - & 2.79 & 7.08 & 8.82 & 7.95 & 35.01 & 19.85 & 42.85 & 37.7 \\
\hline
\end{tabular}

Top level is within $1 \mathrm{~m}$ from sea surface. Bottom level is within $1 \mathrm{~m}$ above seabed. Middle level is the middle depth. Summer (August 2007); Spring (March 2008).

\subsection{Impact of Salinity}

Salinity impact at the marine area adjacent to the desalination plant occurs when brine containing higher content of salt and minerals above ambient level is discharged through the plant outlet. Changes to salinity can play a significant role in the growth and size of aquatic life and the marine species disturbance. Water salinity was measured at two water depths to assess salinity gradient with depth in relation to the plant discharge effluent. Salinity of water surface during summer ranged between a minimum of 41.06 ppt (at station Zr 2, $300 \mathrm{SE}$ ) and a maximum of 43.75 ppt (at station Zr 8, 500 SSE) with an average 42.79 ppt (Table 3). In the bottom water layer, concentration of salinity was from $41.82 \mathrm{ppt}(\mathrm{Zr} 192000 \mathrm{~m}$ ESE from outlet) to a maximum of $43.75 \mathrm{ppt}(\mathrm{Zr} \mathrm{8}, 500 \mathrm{~m}$ SSE) in the direction of the flow with an average 42.85 ppt. The distribution of water salinity in the surface and bottom layer was small ( $<1$ ppt, Fig. 6$)$.
In Spring, surface water salinity ranged between a minimum of $38.18 \mathrm{ppt}(\mathrm{Zr} \mathrm{8})$ and a maximum of 42.09 ppt ( $\mathrm{Zr} \mathrm{14}$, Table 3) with an average 40.29 ppt. Highest salinities were exhibited in stations between 500 and $1,000 \mathrm{~m}$ towards the northeast and southeast of the outfalls (Fig. 7). Impact close to the outlet was not found high (Fig. 7). At the bottom water layer, salinities ranged between a minimum of $35.20 \mathrm{ppt}(\mathrm{Zr}$ 7) and a maximum of $40.17 \mathrm{ppt}(\mathrm{Zr} \mathrm{11}, 500 \mathrm{~m} \mathrm{NE})$ with an average $39.18 \mathrm{ppt}$. Highest salinities at the bottom layer were exhibited closer to the outlet in the area less than $1,000 \mathrm{~m}$, contrary to the surface water (Fig. 7). The difference of water salinity between the highest measurement recorded in summer and the highest recorded in spring in surface was $1.66 \mathrm{ppt}$, while the difference was $2.88 \mathrm{ppt}$ in the bottom water layer (Table 3). Potential impact of the salinity at the vicinity of the studied area was found to range between 2-4 ppt above mean salinity of seawater in Kuwait in the two seasons. The impact can reach as 

Chemical Properties

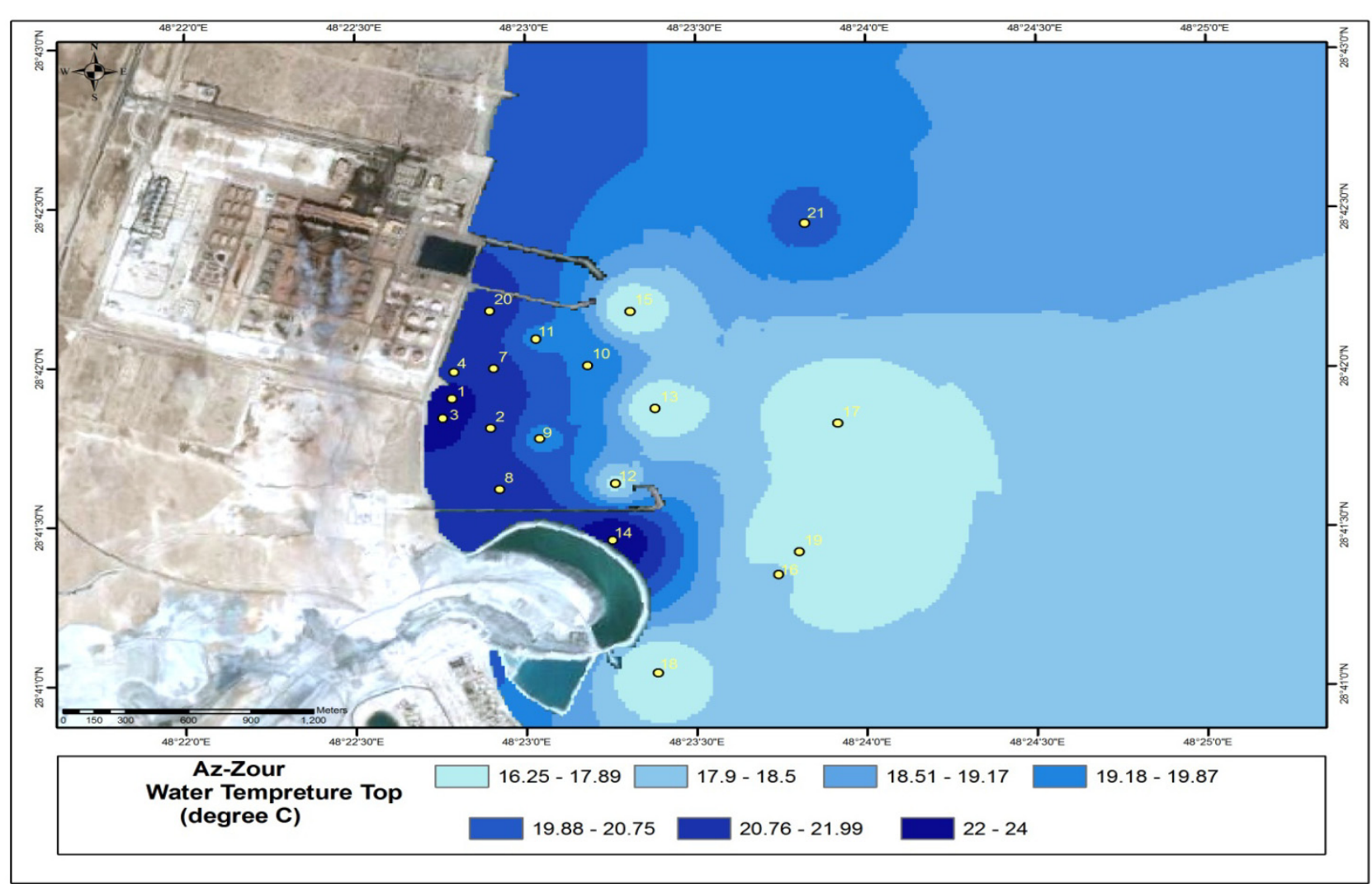

Fig. 4 Spatial distribution of surface water temperature at the vicinity of Az-Zour desalination plant during summer season.

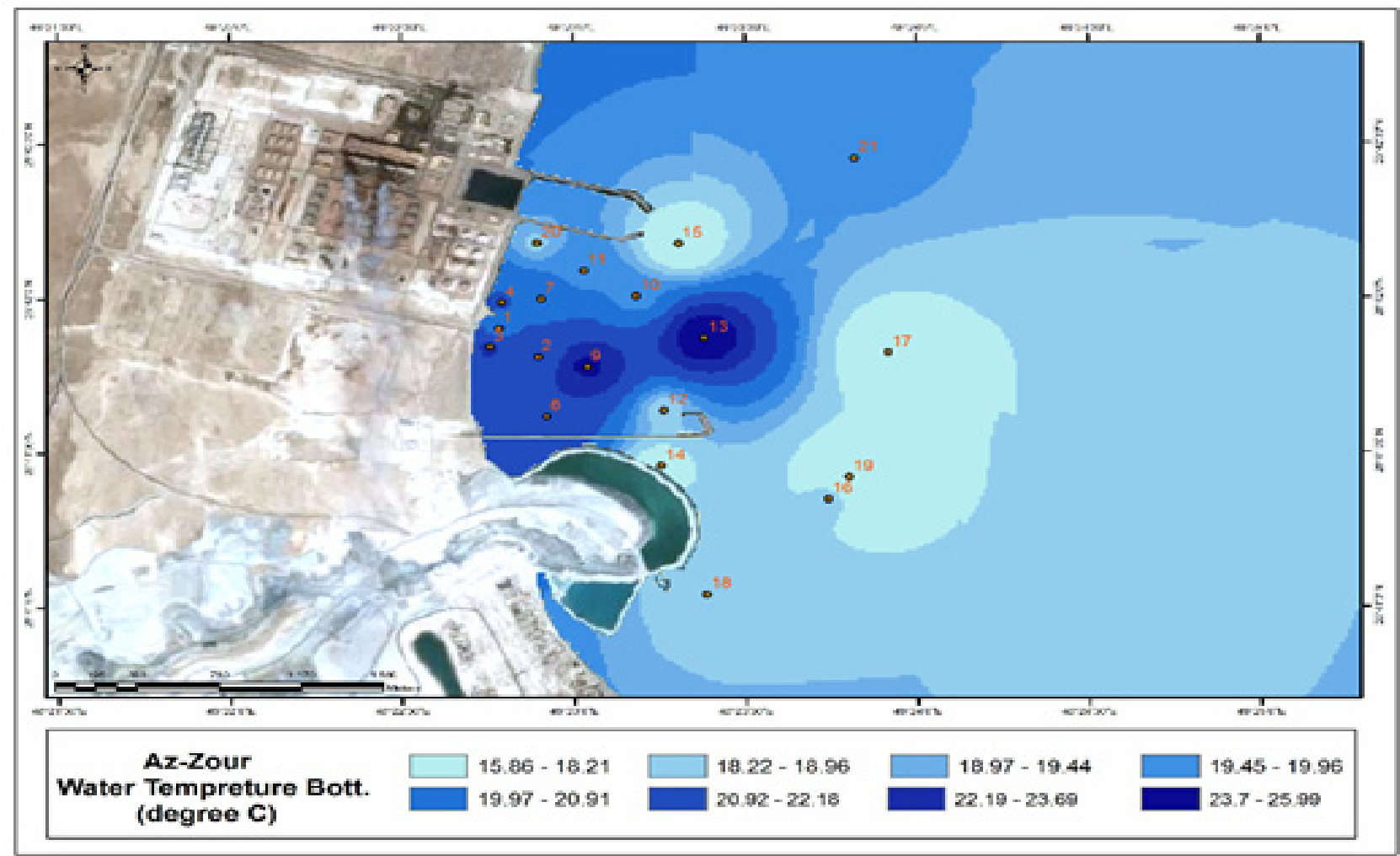

Fig. 5 Spatial distribution of bottom water temperature at the vicinity of $\mathrm{Zr}$ desalination plant during spring season. 

Chemical Properties
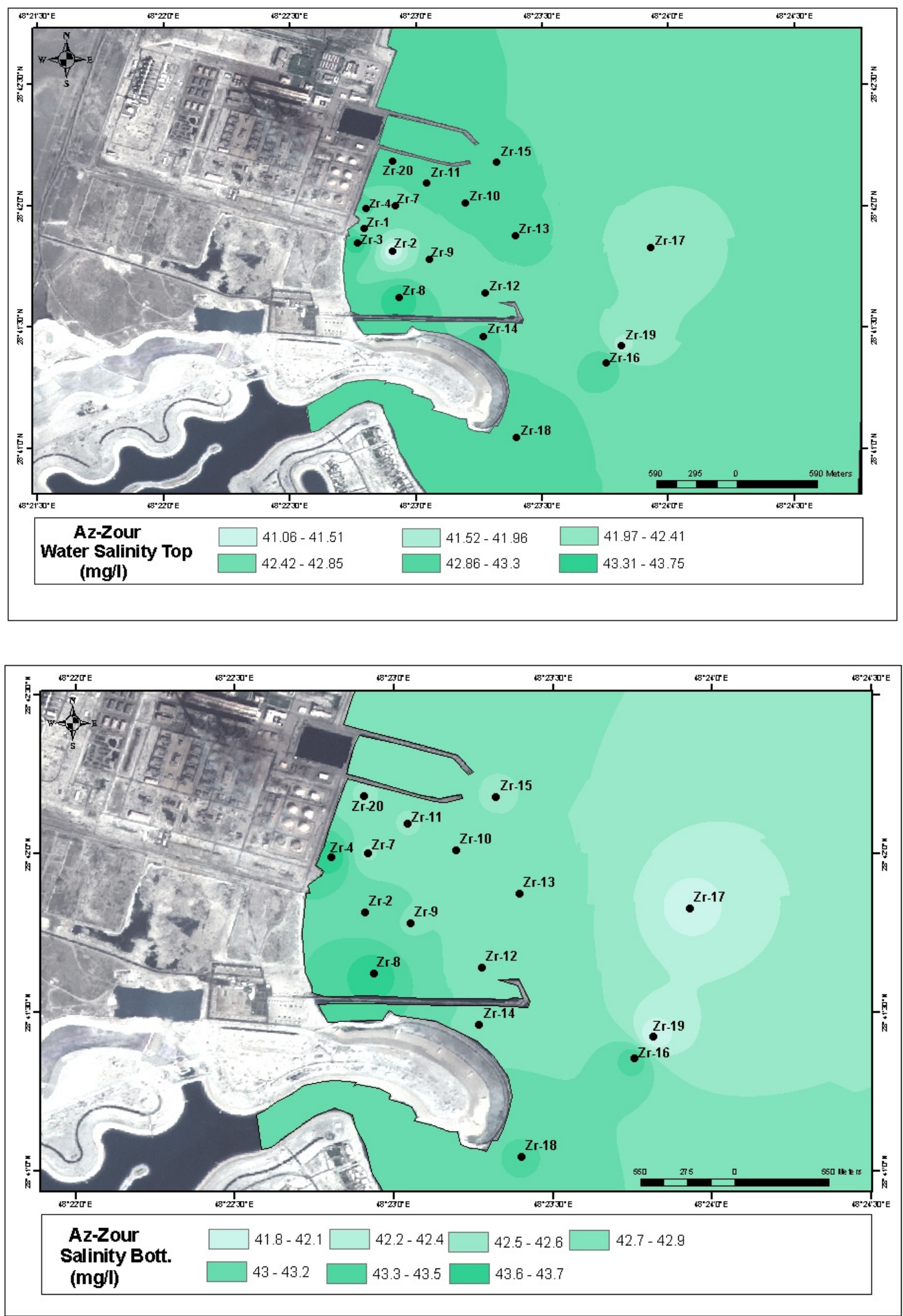

Fig. 6 Spatial distribution of salinity in surface and bottom water layers at the vicinity of Az-Zour desalination plant during summer season. 

Chemical Properties
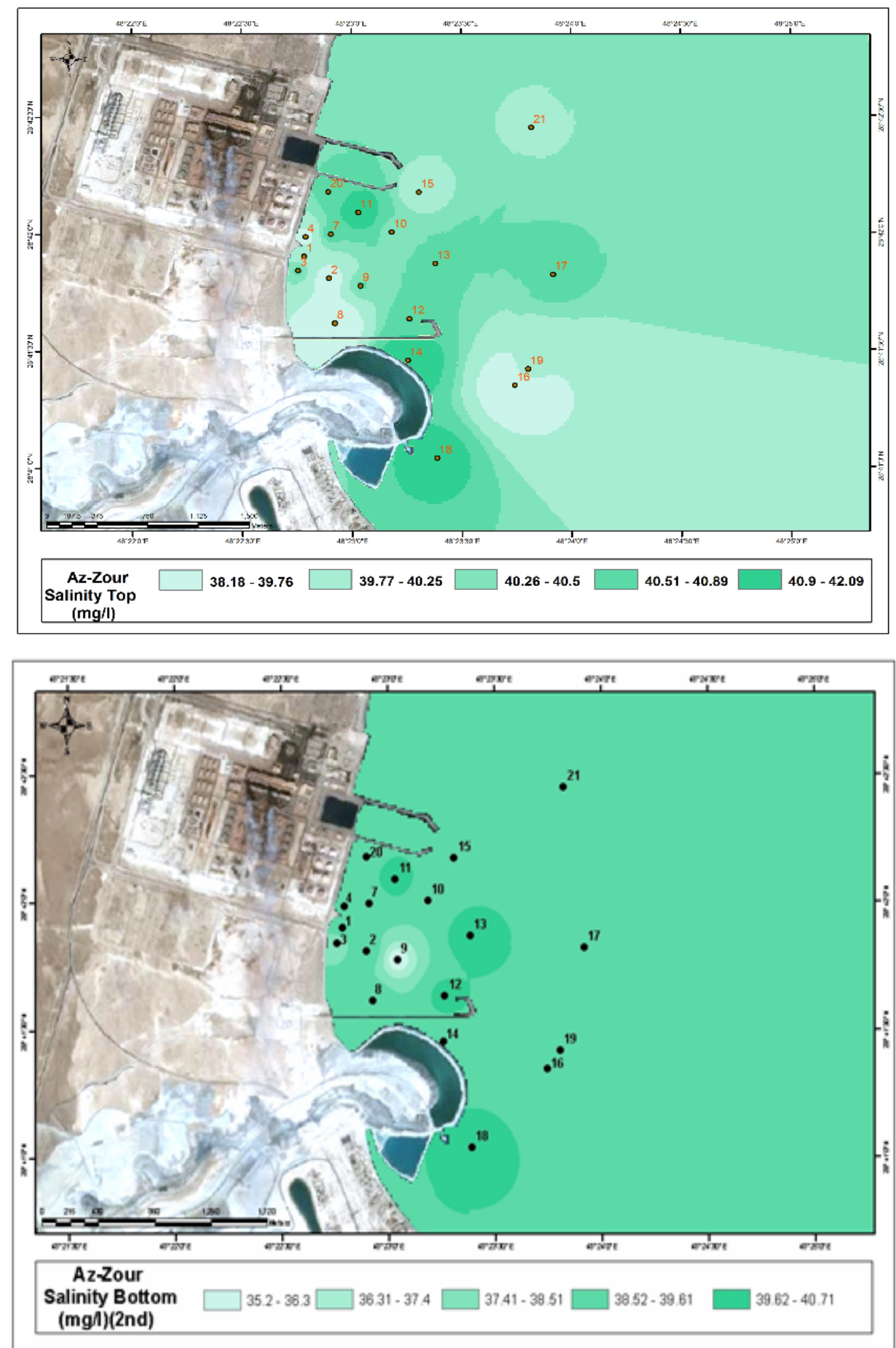

Fig. 7 Spatial distribution of salinity in surface and bottom water layers at the vicinity of Az-Zour desalination plant during spring season. 
far as $1,000 \mathrm{~m}$ away from the plant outfall. The increase in salinity above mean value at the vicinity of the plant is higher than the limit of 33-42 ppt set by Kuwait Environmental Authority (EPA) for seawater quality [17].

\subsection{Impact on $D O$}

Increased temperature and salinity of the discharged effluent from desalination plant reduce the solubility of DO in seawater. Levels of DO may be reduced because of the physical deaeration and addition of oxygen scavenger such as sodium sulphite to inhibit corrosion inside the plants. Table 3 shows the concentrations of DO at the vicinity measured in spring at the two water depths; surface and bottom (no measurements could be made during summer due to instrument failure during fieldwork). In spring, surface DO levels were higher and ranged between a minimum of $6.57 \mathrm{mg} / \mathrm{L}$ ( $\mathrm{Zr} \mathrm{2,} 300 \mathrm{~m}$ southeast the outfall) and a maximum of $7.55 \mathrm{mg} / \mathrm{L}$ recorded at station $\mathrm{Zr} 17$ (2,000 $\mathrm{m}$ east the outfall). EPA monitoring data for DO Az-Zour was $8.8 \mathrm{mg} / \mathrm{L}$ in March 2008 [18]. In the bottom water, DO was found to range between $6.66 \mathrm{mg} / \mathrm{L}(\mathrm{Zr} \mathrm{4}, 100 \mathrm{~m}$ north the outfall) and $7.55 \mathrm{mg} / \mathrm{L}$ at station $\mathrm{Zr} 17$ (2,000 m east the outfall), where in many stations, DO in bottom station was slightly higher than surface water. Normally under stratified conditions, the DO concentration is lower in the bottom layer than in the surface layer, as oxygen is consumed by decaying organic matter. Near the outfall, DO concentration is lower in the surface layer than in the bottom layer. Hence, it is thought that this is a direct result of the outfall. As the outfall plume is slightly buoyant (the density is lower than the receiving seawater), it tends to rise to the surface layer. As the outfall plume has a lower DO concentration, the surface layer shows a lower DO concentration than the bottom layer.

Kuwait has set a minimum standard of $4 \mathrm{mg} / \mathrm{L}$ or $90 \%$ saturation whichever is higher for marine water quality [17]. The above-mentioned results at the vicinity Az-Zour plant showed that DO levels were above this limit.

\subsection{Impact on $p H$ Levels}

At the vicinity of the desalination plant, measurements recorded for $\mathrm{pH}$, expect for station $\mathrm{Zr} 1$ (at the discharge outlet), were all above 8 (ranging from 8.36 to 8.88 ). Surface water $\mathrm{pH}$ levels were similar to the levels in bottom water layer (see Table 3). In spring, $\mathrm{pH}$ levels were higher than in summer and were generally about 8 in most of the stations except at station $\mathrm{Zr} 14$ and $\mathrm{Zr} 12$ where it was found to be slightly lower (7 and 7.4). When compared to surface levels, $\mathrm{pH}$ readings in bottom water showed no significant difference (Table 3) and generally within Kuwait-EPA limits and therefore no significant impact of $\mathrm{pH}$ was observed [17].

\section{Conclusions}

Measurement of temperature at the marine vicinity of the investigated Az-Zour desalination plant showed an increase between 4 and $6{ }^{\circ} \mathrm{C}$ above ambient temperature in which the seasonality conditions were taken into account. In general, temperature showed a decreasing trend from the outfall discharge point toward offshore. On the average, 2 to $3{ }^{\circ} \mathrm{C}$ difference in temperature was noted between stations close to the discharge point, and those further away $(>1.5 \mathrm{~km})$. The hydrodynamic model employed in this study gave a prediction of temperature dispersion near Az-Zour marine areas. It showed that the thermal plume rans parallel to the shoreline. The area influenced by the outfall can reach to about $40 \mathrm{~km}^{2}$. Potential impact of salinity at the vicinity of the Az-Zour plant was found to range between 2-4 ppt above mean salinity of seawater in Kuwait in the two seasons. The impact can reach as far as $1,000 \mathrm{~m}$ away from the plant outfall. The increase in salinity above mean value at the vicinity of the investigated plants is higher than the limit of 33-42 ppt dictated by Kuwait EPA regulations for seawater quality. 


\section{Chemical Properties}

\section{Acknowledgments}

The authors would like to thank Kuwait Environment Public Authority (EPA) for the financial support given to carry out this project and Kuwait Institute for Scientific Research for their continuous support. Data used in this study were collected during the execution of a project entitled "Impact of Desalination Plants Discharged Effluents on the Marine Environment in Kuwait”.

\section{References}

[1] Hamoda, M. 2001. "Desalination and Water Resource Management in Kuwait." Desalination 138: 385-93.

[2] MEW. 2015. Annual report, Ministry of Electricity and Water, Kuwait.

[3] Hoepner, T. 1999. "A Procedure for Environmental Impact Assessments (EIA) for Seawater Desalination Plants." Desalination 124: 1-12.

[4] UNEP. 2006. "Protecting Coastal and Marine Environments from Land-Based Activities: A Guide for National Action." UNEP/GPA, The Hague, ISBN 92-807-2710-9.

[5] Abdel-Jawad, M., and Al-Tabtabaei, M. 1999. "Impact of Current Power Generation and Water Desalination Activities on Kuwaiti Marine Environment." In Proceedings of IDA World Congress on Desalination and Water Reuse, San Diego, California, USA, August 29-September 3.

[6] Lattemann, S., and Hopner, T. 2007. "Seawater Desalination: Impacts of Brine and Chemical Discharge on the Marine Environment." Balaban Desalination Publications, Italy, ISBN 0-86689-062-9.

[7] Abdul Raheem, M. 2007. "Reducing the Ecological Footprint of Power/Desalination Plants." In Symposium Proceeding towards Innovative Desalination and Power Generation in Kuwait, Kuwait Foundation for the
Advancement of Sciences, 9-11.

[8] Hashim, A., and Hajjaj, M. 2005. "Impact of Desalination Plants Fluid Effluents on the Integrity of Seawater, with the Arabian Gulf in Perspective." Desalination 182 (1-3): 373-93.

[9] Huges, P., and Hunter, J. R. 1979. "Physical Oceanography and Numerical Modeling of the Kuwait Action Plan Region, Report Marine.” UNESCO Division of Marine Sciences.

[10] Hunter, J. R. 1983. "Aspects of the Dynamics of the Residual Circulation of the Arabian Gulf." In Coastal Oceanography, edited by Gade, H. G., Edwards, A., and Svedsen, H., New York, NY: Plenum Press, 31-42.

[11] Reynolds, R. M. 1993. "Physical Oceanography of the Gulf, Straits of Hormuz, and the Gulf of Oman: Results from the Mt. Mitchell Expedition." Marine Pollution Bulletin 27: 35-59.

[12] NOAA. 1993. National Oceanic and Atmospheric Administration (NOAA) Office (http://www.ngdc.noaa.gov/ngdc.html).

[13] Al-Yamani, F., Bishop, Y., Morgan, G., Kwarteng, R. A., Al-Ghadban, A., and Sheppared, C., 1995. "Assessment of the Effect of the Shatt Al-Arab's Altered Discharge Regimes on the Ecology of Northern Arabian Gulf". KISR No. FM 006K.

[14] Al-Tayaran, A., and Madany, I. 1992. "Impact of a Desalination Plant on the Physical and Chemical Properties of Seawater, Bahrain." Water Research 26: 435-41.

[15] MOOPAM. 1999. Manual of Oceanographic Observations and Pollutant Analysis Methods. Kuwait: Regional Organization for the Protection of the Marine Environment (ROPME).

[16] AWWA Organization Manuals. 2005. Standard Methods for the Analysis of Water and Wastewater (21th ed.). USA: APHA-AWWA-WPCF.

[17] EPA. 2001. Environmental Regulations and Standards of Kuwait. Al-Kuwait Alyoum, Issue No. 533.

[18] EPA. 2008. Monthly Monitoring Report of Water in Kuwait. Environment Public Authority. 